\title{
Factors at first diagnosis of tuberculosis associated with compliance with the Directly Observed Therapy (DOT) in the Limpopo Province, South Africa
}

\author{
K Peltzer, Health Behaviour Research Unit, University of the North \\ $H$ Onya, Health Promotion Unit, University of the North \\ P Seoka, Health Behaviour Research Unit, University of the North \\ FM Tladi, Department of Nursing, University of the North \\ RN Malema, Department of Nursing, University of the North
}

\begin{abstract}
The aim of this study is to compare and contrast health beliefs, demographic and socio-economic variables, causative beliefs, knowledge, health-seeking behaviour and health provider-patient interaction of compliant and non-compliant tuberculosis patients. The sample included 219 consecutive new sputum-smear and/or culture positive pulmonary tuberculosis patients registered between October 1999 and March 2000 in three hospitals in the Limpopo Province of South Africa. The patients were $144(65.8 \%)$ men and $75(34.2 \%)$ women in the age range of 18 to 79 years $(M$ age $35.9 \mathrm{yr}$., $S D=12.6$ ). The consultation at first diagnosis was observed and tape-recorded. Thereafter an interview was conducted and a questionnaire was face-to-face administered with the patient including knowledge, causative beliefs, health seeking, and Health Belief Model items. Discriminant analysis between compliant and non-compliant groups after six months follow-up showed that the quality of the health practitioner-patient interaction and causative belief were associated with compliance behaviour whereas knowledge, onset of TB, sociodemographic variables, health care seeking, and health beliefs were not associated.
\end{abstract}

\section{Introduction}

South Africa is burdened by one of the worst tuberculosis epidemics in the world, with disease rates more than double those observed in other developing countries and up to 60 times higher than those currently seen in the USA or Western Europe. The Medical Research Council estimated that the country had an estimated 180507 cases (55\% reported) in 1997 , or 419 per 100000 of the total population; of these, $32,8 \%$ ( 73679 cases) were probably infected with HIV (Fourie, 2000: 4f.). Estimates by the MRC National Tuberculosis Programme indicate that current trends in the epidemic will continue unless effective control is achieved, resulting in 3,5 million new cases of tuberculosis over the next decade and at least 90000 patients dying. On the other hand, significant reductions in transmission of HIV infection together with effective tuberculosis control would mean a turn-around in the tuberculosis epidemic by the year 2003 (Fourie, 2000: 5f.). In comparison with the MRC estimates based on epidemiological modelling as mentioned above, actual registration reports to the National Department of Health indicated smear positive rates per province (per 100000 of the total population) of 285 for the Western Cape, 300 for the Eastern Cape and 328 for the Northern Cape. All other provinces had rates below 200. The overall rate for South Africa was 163 for smear positive and 310 for all pulmonary tuberculosis cases (Fourie,
2000: 7f.).

Tuberculosis was declared a top health priority by the Department of Health in November 1996 and National Health Minister Zuma committed her Department to implementing a new control programme based on the DOT strategy of the World Health Organisation. The pace and extent of implementation of the programme is, however, slow in most provinces. Since 1996, a system of case registration based on strict criteria for case definition was implemented in South Africa. These registrations, based on standardised criteria, are now beginning to present a clearer picture of disease rates in the country than what was available before. Some progress is being made in certain provinces in South Africa (Wilkinson \& Davies, 1997: 700) Mpumalanga (despite relatively high HIV rates) and the Western Cape are already showing dramatic improvements in cure rates, because of disciplined implementation of the DOT strategy of the WHO in these provinces. Other provinces are at various stages of implementation of the process such as the Limpopo Province (Fourie, 2000: 10). Factors identified for the improvement of the DOT strategy from research are implementation of the DOT right from the beginning of diagnosis, culturally determined beliefs about and knowledge of tuberculosis, adherence of TB treatment (Rubel \& Garro, 1992: 626), transportation time, the sex of the patient, patient information and the quality of communication between patients and health workers (Comolet, 
Rakotomalala \& Rajaoarioa, 1998: 891), substance abuse, emotional disturbance, homelessness, lack of transportation, behavioural problems, dissatisfaction with clinic scheduling, forgetfulness, mental retardation, lack of family or social support, migrant status, illiteracy, unemployment, and low income (Sumartojo, 1993: 1311). Glatthaar and Berends (1995: 179) have shown how DOT with a community approach reached a $90 \%$ adherence rate in an urban (Cape Town) area. Jaramillo (1999: 71) reviews that low levels of self-efficacy, poor information about TB and its means of control and the stigma attached to the disease (with the social discrimination it entails) contribute to some extent to poor adherence to treatment. Furthermore, he states that material support (food, money, fees for transport, etc.) and personal/family income has been reported as a predictor of the outcome of TB control programmes. Barnhoorn and Adriaanse (1992: 291) identified that the presence of social support (in particular the presence of a supportive person, who establishes routine in taking pills and in making control visits) and satisfaction with health-care providers contributed positively to compliance. Westaway and Wolmarans (1994: 447) found among black urban South African TB patients that case-holding (compliance for both patient and system) involves complex behaviours that depend upon symptom recognition and evaluation, cultural and social influences and enabling factors such as time, money, skills and appropriate/accessible health services. Rideout and Menzies (1994: 3) stated that tuberculosis control programmes must be tailored to take into account the importance of cultural factors in promoting compliance with therapy. In many cultures, the largely unremarked social stigma of tuberculosis contributes to abandonment of treatment and lengthy delays in seeking professional care (Rubel \& Garro, 1992: 626).

\section{Statement of the problem}

The DOT strategy has been shown to be more cost effective than conventionally delivered treatment for the treatment of new cases of tuberculosis in adults in South Africa (Floyd, Wilkinson \& Gilks, 1997: 1407f.; Westaway, Conradie, \& Remmers, 1991: 447). However, the implementation of the DOT strategy in the Limpopo Province has been slow. Several studies have identified factors for the improvement of DOT strategy (Glatthaar \& Barends, 1995: 179; Garner, 1998: 1326; Rubel \& Garro, 1992: 626; Comolet et al., 1998: 892; Sumartojo, 1993: 1311ff.). Other studies have suggested additional factors to be considered (Jaramillo, 1999: 71; Barnhoorn \& Adriaanse, 1994: 291f.). These studies were urban-based and did not focus on rural black South Africans. Westaway and Wolmarans (1994: 447) studied black South African TB patients but this study was also urban-based. There is paucity of information on DOT strategy in South Africa. This information has not resulted in significant improvement of the pace, extent of implementation and effectiveness of DOT programme in the Limpopo Province. This study aims to investigate the predisposing, reinforcing and enabling factors, which can improve the delivery of DOT programme in three predominantly rural black communities in the Limpopo Province of South Africa.

\section{Theorectical models}

Directly observed therapy is predicated on the belief that by directly observing the patient consume all required medications, a full treatment regimen will be ensured, thereby reducing the risk of treatment failure (Nazar-Stewart \& Nolan, 1992: 58).

The health belief model (HBM) has proven to be a useful framework for examining sick role behaviours such as compliance. It assumes that people comply with regimes under a very specific set of conditions. Patients must possess some minimal level of health knowledge and motivation towards health. They must see themselves as vulnerable to the illness and believe that the illness is of a serious nature. Additionally, they must be convinced that the treatment can be efficacious, i.e. that it is actually possible to obtain control over the disease and that the cost of such control is not too high in view of the benefits. Another factor included in the model is the predisposition, or motivation, of people to engage in health-related practices (Barnhoorn \& Adriaanse, 1992: 300).

Effective care for patients also requires understanding of one's ethnic identity and related conception of illness. Kleinman (1980: 80f.) referred to developing an openness to each patient's own 'explanatory model' of illness. Because of their primary contact with the patient, health care providers can strongly affect the patient's commitment to a correct regimen, particularly by means of clear communication about the regimen.

\section{Aims and objectives}

The aim of this study is to compare and contrast health beliefs, demographic and socio-economic variables, causative beliefs, knowledge, health-seeking behaviour, and health provider-patient interaction of compliant and non-compliant tuberculosis patients. If the model distinguishes well between both groups, it would be important to identify what dimensions have the greater impact on patient compliance and which ones are appropriate to serve as a basis for planning educational and health promotive interventions for the improvement of the DOT strategy in the three main cultural groups and three regions in the Limpopo Province of South Africa.

\section{Methods \\ Design}

The design of the study was a prospective case control study divided into (1) assessment of first diagnosed pulmonary tuberculosis patients, and (2) follow-up of the diagnosed tuberculosis patients. Here only the follow-up statistics are used in the analysis. The detailed results of the follow-up study are reported elsewhere (Peltzer, 2001: 191).

\section{Sample}

The sample included 219 consecutive new sputum-smear and/ or culture positive pulmonary tuberculosis patients registered between October 1999 and March 2000 in three hospitals (74 
in Tsilidzini, 80 in Letaba and 65 in Pietersburg-MankwengGroothoek hospitals). Criteria for inclusion in our study were: (a) formal informed consent, (b) age 18 years or older, and (c) no previous treatment history. All patients received super-

Table 1: Sociodemographic characteristics $(N=219)$

\begin{tabular}{|c|c|c|c|}
\hline \multicolumn{2}{|c|}{ Sociodemographic characteristics } & No & $(\%)$ \\
\hline \begin{tabular}{|l|}
$\begin{array}{l}\text { Place of } \\
\text { residence }\end{array}$ \\
\end{tabular} & \begin{tabular}{|l|}
-Village \\
-Urban \\
\end{tabular} & $\begin{array}{l}188 \\
031 \\
\end{array}$ & $\begin{array}{l}85.5 \\
14.2 \\
\end{array}$ \\
\hline Family type & \begin{tabular}{|l|}
-Nuclear \\
-Joint
\end{tabular} & \begin{tabular}{|l|}
139 \\
080 \\
\end{tabular} & \begin{tabular}{|l|}
63.5 \\
36.5 \\
\end{tabular} \\
\hline Marital status & $\begin{array}{l}\text {-Married/living with partner } \\
\text {-Single } \\
\text {-Divorced/widowed }\end{array}$ & $\begin{array}{l}104 \\
092 \\
023\end{array}$ & $\begin{array}{l}47.5 \\
42.0 \\
10.5\end{array}$ \\
\hline $\begin{array}{l}\text { Formal } \\
\text { education }\end{array}$ & \begin{tabular}{|l}
-None \\
-Primary: \\
-Secondary \\
-Tertiary
\end{tabular} & \begin{tabular}{|l|}
28 \\
68 \\
103 \\
20
\end{tabular} & $\begin{array}{l}12.8 \\
23.1 \\
47.0 \\
09.1\end{array}$ \\
\hline $\begin{array}{l}\text { Occupation of } \\
\text { patient }\end{array}$ & $\begin{array}{l}\text {-None } \\
\text {-Housewife } \\
\text {-Gardener, domestic worker } \\
\text {-Security, driver, mechanic } \\
\text {-Police officer, secretary } \\
\text {-Teacher, nurse } \\
\text {-Lecturer, businessman, manager }\end{array}$ & $\begin{array}{l}81 \\
08 \\
37 \\
75 \\
08 \\
05 \\
04\end{array}$ & $\begin{array}{l}37.0 \\
03.7 \\
16.9 \\
34.2 \\
03.7 \\
02.3 \\
01.8\end{array}$ \\
\hline Type of house & \begin{tabular}{|l}
-Brick house with tiles \\
-Brick house with corrugated iron \\
-Mud house with corrugated iron \\
-Thatched mud house \\
-Other
\end{tabular} & $\begin{array}{l}10 \\
126 \\
25 \\
41 \\
17\end{array}$ & $\begin{array}{l}04.6 \\
57.5 \\
11.4 \\
18.7 \\
07.8\end{array}$ \\
\hline Type of fuel & $\begin{array}{l}\text {-Firewood } \\
\text {-Electricity } \\
\text {-Paraffin } \\
\text {-Other }\end{array}$ & $\begin{array}{l}110 \\
60 \\
43 \\
06\end{array}$ & $\begin{array}{l}50.2 \\
27.4 \\
19.6 \\
02.7\end{array}$ \\
\hline $\begin{array}{l}\text { Monthly } \\
\text { income }\end{array}$ & \begin{tabular}{|l|} 
None \\
$-1-999 \mathrm{R}$ \\
$-1000-2999 \mathrm{R}$ \\
$-3000-6999 \mathrm{R}$ \\
\end{tabular} & $\begin{array}{l}93 \\
51 \\
39 \\
19\end{array}$ & $\begin{array}{l}42.5 \\
23.3 \\
17.8 \\
08.7\end{array}$ \\
\hline $\begin{array}{l}\text { Relation with } \\
\text { head of family }\end{array}$ & $\begin{array}{l}\text {-Self } \\
\text {-Son } \\
\text {-Daughter } \\
\text {-Wife } \\
\text {-Brother/sister } \\
\text {-Grandchild } \\
\end{array}$ & $\begin{array}{l}61 \\
64 \\
36 \\
32 \\
11 \\
08\end{array}$ & $\begin{array}{l}27.9 \\
29.2 \\
16.4 \\
14.6 \\
05.0 \\
03.7\end{array}$ \\
\hline Religion & $\begin{array}{l}\text {-African/traditional } \\
\text {-Zion } \\
\text {-Apostolic } \\
\text {-Christian Protestant } \\
\text {-Christian Catholic } \\
\text {-Other }\end{array}$ & $\begin{array}{l}89 \\
55 \\
11 \\
34 \\
15 \\
17\end{array}$ & $\begin{array}{l}40.6 \\
25.1 \\
05.0 \\
15.5 \\
06.8 \\
07.8\end{array}$ \\
\hline
\end{tabular}


vised therapy with $\mathrm{RHZE}$ ( $\mathrm{R}=$ rifampicin, $\mathrm{H}=\mathrm{isoniazid}$, $\mathrm{Z}=$ pyrazinamide, $\mathrm{E}=$ =thambutol) 5 times weekly for 8 weeks, followed by RH 5 times weekly for 16 weeks. The patients were $144(65.8 \%)$ men and $75(34.2 \%)$ women in the age range of 18 to 79 years ( $M$ age $35.9 \mathrm{yr}$, $S D=12.6$ ). Distribution by ethnicity showed $101(46.1 \%)$ Northern Sotho, 65 $(29.7 \%)$ Venda, $48(21.9 \%)$ Tsonga, and 5 (2.3\%) others.

\section{Research instrument}

(1) A 46-item scoring key for the health carer patient consultation (Boesch, 1988: 253ff.). Items include for example: "How does the doctor start the consultation?", "Symptom question concerning cause", "Explaining of cause by doctor", "Personal question related to symptom or other health question", and "Explanation of treatment and medicine by doctor".

(2) A recall interview of the patient on the consultation (Boesch, 1988: 250)

(3) Fifteen items on demographic and socio-economic data. swered by yes or no) (.62). (cf. Steen \& Mazonde, 1999: 163)

(10) Three items on the curability of health care agents (rated from 1=agree to 3=disagree). (cf. Steen \& Mazonde, 1999: 164)

(11) A 21-item questionnaire based on the Health Belief Model developed by Barnhoorn \& Adriaanse (1992: 302): (a) health motivation ( 5 items) (.64 indicates the Cronbach alpha for this study sample), (b) perceived susceptibility (4 items) (.61), perceived severity (4 items $)(.62)$, perceived benefits ( 4 items $)(.70)$, and perceived barriers or costs (4 items)(.66) (rated from $1=$ strongly agree to $6=$ strongly disagree). The overall alpha coefficient was .67 indicating the Cronbach alpha for this study sample.

(12) Assessment of compliance. The criterion for labelling a patient to be "non-compliant" was the failure to take anti-tuberculosis medication for more than two weeks duration. This was assessed by a) number of pills taken (checked ticks on green card and number of pills pre-

\section{Table 2: Group means, standard deviations and significance tests of sociodemographic variables for the compliant and non-compliant groups}

\begin{tabular}{|l|l|l|l|}
\hline Variables & $\begin{array}{l}\text { Compliant }(\mathrm{n}=81) \\
\mathrm{M}(\mathrm{SD})\end{array}$ & $\begin{array}{l}\text { Non-compliant }(\mathrm{n}=55) \\
\mathrm{M}(\mathrm{SD})\end{array}$ & $\begin{array}{l}\text { Univariate } \\
\text { F-ratio }\end{array}$ \\
\hline Sex & $0.34(0.48)$ & $0.26(0.44)$ & .592 \\
\hline Age & $35.3(13.8)$ & $34.4(13.0)$ & .091 \\
\hline Marital status & $0.46(0.50)$ & $0.52(0.51)$ & .236 \\
\hline Family type & $0.72(0.97)$ & $0.58(0.92)$ & .410 \\
\hline Family size & $6.52(3.26)$ & $6.68(2.53)$ & .053 \\
\hline Place of residence & $1.08(0.27)$ & $1.03(0.18)$ & .741 \\
\hline Education & $2.32(1.15)$ & $2.26(1.21$ & .053 \\
\hline Occupation & $2.66(1.36)$ & $2.55(1.59)$ & .113 \\
\hline Family's monthly income & $1.06(1.27)$ & $1.03(1.22)$ & .009 \\
\hline Type of house & $4.00(1.34)$ & $4.13(1.34)$ & .178 \\
\hline Type of fuel & $1.70(1.15)$ & $2.19(1.33)$ & 3.138 \\
\hline Religion & $0.90(0.81)$ & $0.68(0.65)$ & 1.654 \\
\hline
\end{tabular}

(4) Four items on family and community history and attitudes of tuberculosis.

(5) Two items on drinking and tobacco use status.

(6) The Problem Portrait Technique on causative beliefs of tuberculosis (see Table 4) (MacLachlan, 1997: 849).

(7) Six items on transmission knowledge of tuberculosis (rated from $1=$ strongly agree to $6=$ strongly disagree) (Metcalf, Bradshaw \& Stindt, 1990: 408) (.68, indicates the Cronbach alpha for this study sample).

(8) Nine items on when to stop tuberculosis treatment (rated from $1=$ strongly agree to $6=$ strongly disagree) (Metcalf et al., 1990: 410)(.67).

(9) Seven items on previous health-seeking behaviour (an- scribed checking the container), and b) number of appointments kept and scheduled. Patient's treatment outcome, coded 0 if patient had complied and 1 if patient had failed to comply, was used as dependent variable.

\section{Procedure}

Permission was obtained from the University of the North Ethics Committee and the Provincial Health and Welfare Department.

Before consultation the tuberculosis patient was identified 
from the files and asked for formal consent to participate in the study. Then the patient was accompanied by one of the researchers to the consultation. The consultation was observed by one of the researchers (P Seoka) and two trained research assistants and tape-recorded. Thereafter an interview was conducted and a questionnaire was face-to-face administered with the patient. This included a recall interview on the health provider- patient interaction.
The questionnaires were translated and back translated by bilingual experts in the major languages used in the study according to scientific standard procedures. The schedule was field tested before the survey and modified where necessary.

\section{Data analysis}

The health professional-patient consultation was analysed

Table 3: Onset of tuberculosis for the compliant and non-compliant groups

\begin{tabular}{|c|c|c|c|}
\hline When did the illness start & $\begin{array}{l}\text { Compliant } \\
(\mathrm{n}=81) \\
\text { No }(\%)\end{array}$ & $\begin{array}{l}\text { Non-compliant } \\
(\mathrm{n}=55) \\
\text { No }(\%)\end{array}$ & $\mathrm{X}^{2}$ \\
\hline Less than 4 weeks & $29(39.7)$ & $14(26.9)$ & \multirow[t]{5}{*}{4.727} \\
\hline $1-2$ months ago & $11(15.1)$ & $14(26.9)$ & \\
\hline $2-3$ months ago & $10(13.7)$ & $7(13.5)$ & \\
\hline 3-4 months ago & $12(16.4)$ & $6(11.5)$ & \\
\hline 4 months and more & $11(15.1)$ & $11(21.2)$ & \\
\hline & $M(S D)$ & $M(S D)$ & F-ratio \\
\hline $\begin{array}{l}\text { How many months ago did the } \\
\text { sickness begin? }\end{array}$ & $2.62(1.87)$ & $2.85(1.93)$ & .446 \\
\hline
\end{tabular}

Table 4: Group means, standard deviations and significance tests of tuberculosis causative beliefs from Problem Portrait Technique (PPT) rated from 0 to 10 indicating the importance of the behaviour (10 being most important) as well as frequency of agreed responses (in percent) for the compliant and non-compliant groups

\begin{tabular}{|l|l|l|l|l|l|}
\hline \multirow{2}{*}{ Causative beliefs } & \multicolumn{2}{|l|}{ Compliant $(\mathrm{n}=81)$} & \multicolumn{2}{l|}{ Non-compliant $(\mathrm{n}=55)$} & Univariate \\
\cline { 2 - 6 } & $\mathrm{M}(\mathrm{SD})$ & No $(\%)$ & $\mathrm{M}(\mathrm{SD})$ & No (\%) & F-ratio \\
\hline Dust & $2.31(3.20)$ & $31(38.3)$ & $1.81(3.21)$ & $15(27.3)$ & .773 \\
\hline Smog/smoke & $0.57(1.70)$ & $9(11.1)$ & -- & -- & $5.933^{*}$ \\
\hline Heredity & $0.27(1.41)$ & $3(3.7)$ & $0.70(2.33)$ & $5(9.1)$ & 1.752 \\
\hline $\begin{array}{l}\text { Infected by spouse (sex) } \\
\text { partner }\end{array}$ & $0.68(2.24)$ & $7(8.6)$ & $1.45(2.93)$ & $13(23.6)$ & 2.990 \\
\hline Hard work & & & & & \\
\hline Tobacco smoking & $0.67(1.92)$ & $9(11.1)$ & $0.79(2.28)$ & $6(10.9)$ & .118 \\
\hline Ciment dust & $2.28(3.63)$ & $26(32.1)$ & $3.85(4.07)$ & $27(40.1)$ & $5.403^{*}$ \\
\hline Alcohol & $0.31(1.45)$ & $4(4.9)$ & $0.87(2.53)$ & $6(10.9)$ & 2.638 \\
\hline Germs & $1.51(3.00)$ & $18(22.2)$ & $1.45(2.75)$ & $13(23.6)$ & .011 \\
\hline Dirty environment & $2.73(3.47)$ & $33(40.7)$ & $1.45(2.66)$ & $13(23.6)$ & $5.177^{*}$ \\
\hline Witchcraft & $0.69(1.96)$ & $10(12.3)$ & $1.25(2.81)$ & $10(8.2)$ & 1.809 \\
\hline Makgoma\# & $0.48(1.90)$ & $5(6.2)$ & $0.45(1.88)$ & $4(5.6)$ & .007 \\
\hline Poor eating habits & $0.32(1.69)$ & $3(3.7)$ & $0.58(2.13)$ & $4(7.3)$ & .637 \\
\hline
\end{tabular}

$* * * p<.001, * * p<.01,{ }^{*} p<.05$

\# Assortment of ailments which follows the breach of particular taboos (Peltzer, 1998) 
using a 46-item scoring key (Boesch, 1988: 253ff.). The taperecorded patient-doctor consultation and recall interview of the patient on the consultation were transcribed from the vernacular language to English according to scientific standard procedures. The messages from the health professional (=messages given) and the messages recalled by the patient were content analysed using the following categories: diagnosis, treatment course, treatment duration, support available, prognosis, treatment adherence, results of non-compliance (see appendix II) (Boesch, 1988: 250). Causative beliefs of tuberculosis from the Problem Portrait Technique were content and $92(42 \%)$ were single. Almost half (47\%) had (some) secondary education and $28(12.8 \%)$ were illiterate. Ninetythree $(42.5 \%)$ did not have any monthly income and the majority were either having unskilled or semi-skilled occupations.

Table 1 indicates the sociodemographic characteristics of first diagnosed tuberculosis patients in all three research sites.

Typically the tuberculosis patient is a middle-aged male, married or cohabits, lives in the rural area, comes from a nuclear family, has a semi-skilled occupation, has secondary educa-

Table 5: Help-seeking behaviour for tuberculosis other than biomedical prior to first diagnosis

\begin{tabular}{|l|l|l|l|}
\hline Help-seeking for TB & $\begin{array}{l}\text { Compliant } \\
(\mathrm{n}=81) \\
\text { No }(\%)\end{array}$ & $\begin{array}{l}\text { Non-compliant } \\
(\mathrm{n}=55) \\
\text { No }(\%)\end{array}$ & $\mathrm{X}^{2}$ \\
\hline 1. Used home remedies for TB & $22(27.5)$ & $17(30.9)$ & .438 \\
\hline 2. Use of herbs & $22(27.2)$ & $15(27.3)$ & .000 \\
\hline 3. Used warm fluid/water & $28(35.0)$ & $27(49.1)$ & 2.680 \\
\hline 4. Over-the-counter drugs & $35(44.3)$ & $23(42.6)$ & .038 \\
\hline 5. Visited traditional healer & $20(25.0)$ & $16(29.1)$ & 1.816 \\
\hline 6. Visited faith healer & $13(16.3)$ & $13(23.6)$ & 2.750 \\
\hline
\end{tabular}

${ }^{* * *} p<.001,{ }^{* *} p<.01,{ }^{*} p<.05$

\section{Table 6: Knowledge about transmission of tuberculosis (rated from 1=strongly agree to $5=$ strongly disagree)}

\begin{tabular}{|l|l|l|l|}
\hline Variables & $\begin{array}{l}\text { Compliant } \\
(\mathrm{n}=81) \\
\mathrm{M}(\mathrm{SD})\end{array}$ & $\begin{array}{l}\text { Non-compliant } \\
(\mathrm{n}=55) \\
\mathrm{M}(\mathrm{SD})\end{array}$ & $\begin{array}{l}\text { Univariate } \\
\text { F-ratio }\end{array}$ \\
\hline $\begin{array}{l}\text { 1. Sputum (including standing on } \\
\text { sputum) }\end{array}$ & $1.49(1.04)$ & $1.30(0.77)$ & 1.327 \\
\hline $\begin{array}{l}\text { 2. Air borne (breathing, cough and } \\
\text { droplet spread) }\end{array}$ & $1.31(0.82)$ & $1.13(0.44)$ & 2.249 \\
\hline $\begin{array}{l}\text { 3. Sharing toilet, bath, towels or } \\
\text { clothes }\end{array}$ & $1.96(1.44)$ & $1.98(1.35)$ & .006 \\
\hline 4. Sharing cigarettes, food or drink & $1.59(1.14)$ & $1.46(1.00)$ & .421 \\
\hline 5. Sexually transmitted & $3.29(1.60)$ & $3.09(1.55)$ & .491 \\
\hline 6. Contact with someone with TB & $1.56(1.16)$ & $1.74(1.31)$ & .690 \\
\hline
\end{tabular}

analysed, coded and also analysed statistically (see Table 4) (MacLachlan, 1997: 84-9). Further, descriptive, Chi-square and discriminant statistical analyses were applied using the SPSS (version 10.0).

\section{Results}

The sample included all ( $\mathrm{N}=219)$ first diagnosed pulmonary tuberculosis patients. Most patients $(85.5 \%)$ came from a village and a nuclear family type $(63.5 \%)$. About half of the participants were married or living with a partner $(47.5 \%)$ tion, lives in a brick house with corrugated iron, uses firewood as fuel, has no income or is unemployed, belongs to African traditional religion, and is either the son or the head himself of the family.

In order to identify demographic and socio-economic variables that discriminated between the compliant and non-compliant groups a discriminant analysis was performed for a 
total of 136 patients (81 compliant and 55 non-compliant), which had been successfully followed-up.

From 219 tuberculosis patients assessed at first diagnosis 136 were successfully followed-up after 6 months, $81(59.6 \%)$ had been compliant and $55(40.4 \%)$ had been non-compliant. The compliance rate differed by hospital site from $70.8 \%$ to $41.9 \%$. A large group of patients (82) could not be followed-up due to death, had moved out of the province, and could not been traced. the Problem Portrait Technique.

The compliant group attributed more germs to tuberculosis than the non-compliant group did, whereas the non-compliant group saw smoking tobacco as more responsible for tuberculosis than the compliant group did. The most commonly mentioned causative agents for tuberculosis are believed to be: germs, tobacco smoking, dust, alcohol, dirty environment. and infected by spouse (sex) partner.

\section{Table 7: Knowledge of patients on when to stop treatment (rated from 1=strongly agree to $5=$ strongly disagree)}

\begin{tabular}{|l|l|l|l|}
\hline Variables & $\begin{array}{l}\text { Compliant } \\
(\mathrm{n}=81) \\
\mathrm{M}(\mathrm{SD})\end{array}$ & $\begin{array}{l}\text { Non-compliant } \\
(\mathrm{n}=55) \\
\mathrm{M}(\mathrm{SD})\end{array}$ & $\begin{array}{l}\text { Univariate } \\
\text { F-ratio }\end{array}$ \\
\hline 1. When feeling well & $4.72(0.77)$ & $4.60(1.07)$ & .525 \\
\hline 2. After a period less than six weeks & $4.73(0.73)$ & $4.64(1.06)$ & .327 \\
\hline 3. When side effects are experienced & $4.58(0.88)$ & $4.66(0.87)$ & .275 \\
\hline 4. Depends on how bad it is & $4.55(0.95)$ & $4.72(0.70)$ & 1.170 \\
\hline $\begin{array}{l}\text { 5. On discharge by the doc tor or from } \\
\text { hospital }\end{array}$ & $3.96(1.57)$ & $4.30(1.40)$ & 1.530 \\
\hline 6. When treatment is finished & $3.09(1.88)$ & $3.52(1.89)$ & 1.590 \\
\hline $\begin{array}{l}\text { 7. After a period of six months or } \\
\text { more }\end{array}$ & $1.88(1.49)$ & $2.26(1.68)$ & 1.759 \\
\hline 8. Once radiograph is clear & $3.28(1.63)$ & $3.54(1.62)$ & .764 \\
\hline 9. Once disease is cured & $2.01(1.58)$ & $1.86(1.41)$ & .308 \\
\hline
\end{tabular}

\section{Table 8: Past six months substance use and family and community history of TB}

\begin{tabular}{|l|l|l|l|}
\hline Variables & $\begin{array}{l}\text { Compliant } \\
(\mathrm{n}=81) \\
\text { No (\%) }\end{array}$ & $\begin{array}{l}\text { Non-compliant } \\
(\mathrm{n}=55) \\
\text { No (\%) }\end{array}$ & $\mathrm{X}^{2}$ \\
\hline $\begin{array}{l}\text { Past 6 months alcohol or other } \\
\text { drug use }\end{array}$ & $31(39.2)$ & $19(34.5)$ & .306 \\
\hline Past 6 months tobacco use & $24(30.0 \%)$ & $20(36.4)$ & .601 \\
\hline Family member had TB & $21(25.9)$ & $14(25.5)$ & .004 \\
\hline Community member had TB & $23(28.4)$ & $15(27.3)$ & .020 \\
\hline
\end{tabular}

Table 2 contains the group means of 12 predictor variables for patients (see details in Appendix I), who complied and for those who did not comply with tuberculosis treatment.

None of the variables had significant differences between compliant and non-compliant groups.

Table 3 indicates the onset of tuberculosis symptoms as experienced by the patients.

The non-compliant group had a slightly longer onset of tuberculosis symptoms than the compliant group, which was almost significantly different.

Table 4 indicates the causative beliefs of tuberculosis using
Table 5 indicates the use of alternative health care sources for the treatment of tuberculosis, both since first diagnosis and before first diagnosis of tuberculosis.

Prior to first diagnosis a number of participants from both compliant and non-compliant groups had used alternative healing systems.

Table 6 indicates the patients " knowledge about the transmission of tuberculosis. 
Knowledge on transmission of tuberculosis can generally be considered high regarding sputum, airborne and contact with someone. Falsely sharing toilet, bath, towels or clothes, cigarettes, food or drink was seen by the majority as a route of transmission. There was no significant difference between the compliant and non-compliant group.

Table 7 indicates the awareness of patients on when to stop the treatment

Most patients disagreed with stopping the medication 'when feeling well ' and most agreed with after a period of 6 months or mure. There were no significant differences between compliant and non-compliant group. fied properly, whereas $34.2 \%$ (out of 54 cases) of the noncompliant group was classified correctly.

The health practitioner-patient interaction score was significantly higher among compliant than among non-compliant patients.

Messages given at first diagnosis of TB were in both groups about 4.5 per session and messages recalled were between 3 to 3.5 messages. Examples for messages given and recalled are given in Appendix II.

\section{Discussion}

The study identified the following factors to be associated with compliance with the DOT strategy, which could serve as

\section{Table 9: Group means, standard deviations and significance tests of health beliefs and other variables for the compliant and non-compliant groups (scored from $1=$ strongly agree to $\mathbf{5}=$ strongly disagree)}

\begin{tabular}{|l|l|l|l|}
\hline Variables & $\begin{array}{l}\text { Compliant (n=81) } \\
\text { M (SD) }\end{array}$ & $\begin{array}{l}\text { Non-compliant } \\
(\mathrm{n}=55) \\
\mathrm{M}(\mathrm{SD})\end{array}$ & $\begin{array}{l}\text { Univariate } \\
\text { F-ratio }\end{array}$ \\
\hline Health Belief Model (subscales) & & & \\
\hline 1. Motivation (5 items) & $14.37(5.33)$ & $13.67(4.67)$ & .611 \\
\hline 2. Perceived susceptibility (4 items) & $8.84(2.40)$ & $8.91(2.47)$ & .028 \\
\hline 3. Perceived severity (4 items) & $7.04(2.49)$ & $6.65(2.27)$ & .846 \\
\hline 4. Perceived benefits (4 items) & $6.16(2.33)$ & $5.61(1.65)$ & 2.267 \\
\hline 5. Perceived barriers/costs (4 items) & $9.94(2.79)$ & $10.09(2.62)$ & .195 \\
\hline
\end{tabular}

Table 8 indicates substance use and family and community history of tuberculosis of the participants.

Both past 6 months alcohol and tobacco use seemed with more than $30 \%$ high in both compliant and non-compliant tuberculosis patients. Every fourth (about 25\%) in both groups had a family member who had tuberculosis. There were no significant differences between compliant and non-compliant patients.

Table 9 indicates the components of the Health Belief Model regarding tuberculosis.

Both compliant and non-compliant patients rated tuberculosis as a severe disease, saw strong benefits in taking medication, felt somewhat susceptible towards tuberculosis, and appeared to have not much motivation for treatment. There were no significant differences between the compliant and noncompliant groups. Even the analysis of individual items of the 21-item Health Belief Model questionnaire did not show any significant difference on any item between the compliant and non-compliant group.

Table 10 indicates the analysis of the health practitioner-patient interaction at first diagnosis.

The overall percentage of cases classified correctly was $61.1 \%$. cases out of $81(57.9 \%)$ of the compliant cases were identi- a basis for planning educational and health promotive interventions for the improvement of the DOT strategy in the Limpopo Province:

Case detection; Lesser use of herbs, warm fluid/water, and visiting of traditional and faith healer

In this sample diagnosis of TB was made about 2.7 months after the onset of symptoms. Among a rural sample in Botswana a median delay period of 12 weeks was found for the anti-TB treatment in modern medicine (Steen \& Mazonde, 1999: 165).

In this sample more than $27 \%$ had used herbs, more than $25 \%$ had visited a traditional healer and $43 \%$ over-the-counter drugs prior to TB diagnosis. Steen and Mazonde (1999: 166) also found in Botswana that $52 \%$ of the subjects tried one or more alternative treatments during the delay period. After modern treatment had started in this sample the utilization of alternative treatment modalities dropped, whereas in Botswana $47 \%$ of the subjects visited or planned to visit a traditional or faith healer (Steen \& Mazonde, 1999: 169). Brouwer, Boeree, Kager, Varkevisser and Harries (1998: 232) found that $37 \%$ of TB patients visited a traditional healer before seeking regular medical care in Malawi. In Ethiopia therapeutic preference hinges on the utilization of ethnobotanical remedies (Vechiato, 1997: 185f.). Liefooghe, Baliddawa, Kipruto, Vermeire and De Munynck (1997: 812) reported that the delay in diagnosis of $\mathrm{TB}$, was partly, a result 
of health-care-seeking practices held by PWT.

Demographic and socio-economic factors were not identified as discriminating factors between compliant and noncompliant groups

Liam, Lim, Wong and Tang (1999: 300) also found that compliance with treatment was not affected by age, sex, ethnic group, educational level, occupation, extent of knowledge, tuberculosis symptoms, hospitalisation for tuberculosis. Demographic factors such as age, sex, race, ethnicity, occupation, income, and education are often included in successful treatment of tuberculosis, however, such variables are inconsistent or unreliable predictors of patient adherence (Sumartojo, 1993: 1311). Nuwaha (1997: 690) found in TB patients in Uganda that gender and age was not associated with compliance. Werf, Dade and Van der Mark (1990: 249) found in TB patients in rural Ghana that lower educational level, female gender and younger age was associated with compliance.

Causative beliefs (germs, smog/smoke, and tobacco smoking)

Barnhoorn and Adriaanse (1992: 301) only found witchcraft associated with compliance. Steen and Mazonde (1999: 169) found similar causative beliefs in Botswana such as heavy work, dusty, smoking, from other TB patients, drinking, germs and witchcraft. However, in this sample heredity was also mentioned, likewise in a community sample in the Philippines (Nichter, 1994: 649). Heredity and hard work were of- lungs, predisposing people to TB (Nichter, 1994: 650). DeVilliers (1991: 70) felt that for Xhosa TB patients witchcraft was important. In a study in Honduras $57 \%$ of the TB patients studied believed that they would contract the disease by using the eating utensils of someone afflicted by TB (Mata, 1985: 57). Dalal and Singh (1992: 193) found among hospitalised male TB patients in India that similar causative beliefs as in this study, namely inadequate diet, strenuous work routine, unhygienic practices, and addiction. Scientifically founded beliefs are that TB is not transmitted by sharing meals or cutlery, by kisses, hugs, or sexual relationships.

\section{Knowledge}

In this study both compliant and non-compliant groups seemed to have basic knowledge about tuberculosis in terms of causes, transmission modes and treatment. However, knowledge did not discriminate between compliant and non-compliant group. Other studies have demonstrated that knowledge about an illness, its origins, its dangers, or its treatment in itself does not necessarily lead to improved compliance (Sbarbaro, 1990: 325f.).

Quality of practitioner-patient relationship: Health practitioner-patient interaction score; Quality of communication Enarson, Grosset, Mwinga, Hershfield, O'Brien, Cole and Reichman. (1995: 809) feel that the quality of the patient and provider relationship has a strong influence on treatment adherence. Chaulet (1987: 21) suggests that for improving compliance in TB patients: a personal interview with the patient

\section{Table 10: Analysis of health practitioner-patient interaction}

\begin{tabular}{|l|l|l|l|}
\hline Variables & $\begin{array}{l}\text { Compliant } \\
(\mathrm{n}=81) \\
\mathrm{M}(\mathrm{SD})\end{array}$ & $\begin{array}{l}\text { Non-compliant } \\
(\mathrm{n}=55) \\
\mathrm{M}(\mathrm{SD})\end{array}$ & $\begin{array}{l}\text { Univariate } \\
\text { F-ratio }\end{array}$ \\
\hline $\begin{array}{l}\text { 1. Heal th practitioner-patient interaction } \\
\text { score }\end{array}$ & $9.82(7.90)$ & $6.95(7.09)$ & $3.275^{*}$ \\
\hline $\begin{array}{l}\text { 2. Messages given by health practitioners } \\
\text { (doctor, nurses, DOT coordinator) }\end{array}$ & $4.50(2.48)$ & $4.41(2.55)$ & .022 \\
\hline $\begin{array}{l}\text { 3. Messages recalled by patient (doctor, } \\
\text { nurses, DOT coordinator) }\end{array}$ & $3.04(2.20)$ & $3.50(1.80)$ & 1.171 \\
\hline
\end{tabular}

$* * * p<.001, * * p<.01, * p<.05$

ten reported in Vietnam (Liam, Lim, Wong \& Tang, 1999: 300). Nichter (1994: 650) found among Filipina TB patients that cigarette smoking was associated with TB not only through the perception that smoke was harmful for the lungs, but because it was observed that smoking sometimes reduced appetite. This study found other causative beliefs of lower importance such as hard work and witchcraft. Overwork and exposure to the elements (as well as excessive sexuality) were perceived to weaken the body among Filipinas. Overwork was a risk factor for pulmonya, an illness thought to weaken the lasting at least $20 \mathrm{~min}$, to identify his social, occupational, and family problems, as well as his perception of the disease and its treatment, and the development of personal contact between the patient. the physician, and the nurses throughout treatment. In this study the interview with the physician did not normally include the social history of the patient, occupational and family problems as well as the perception of the disease as it was rated from the health practitioner-patient interaction score. Health care providers do need training on the importance of health education to encourage treatment completion (see also Khan, Walley, Newell \& Naghma, 
2000: 247).

This study found that messages on the instructions by the physician recalled were not associated with compliance. However, the patient recalled more than half of the messages given soon after the consultation. Sbarbaro (1990: 325) reviews that roughly half the statements made to a patient will be forgotten within five minutes.

\section{Patient characteristics}

In this sample about $25 \%$ indicated that they had a family member and $28 \%$ a community member who had had TB. Westaway and Wolmarans (1994: 447-9) found among urban South Africans that $48 \%$ of tuberculosis patients had a family that must be taken into account while designing DOT interventions, which are acceptable and feasible, and therefore likely to be effective in South Africa. Most important of these factors are: quality of health provider - patient relationship and causative belief. They have shown that powerlessness can be thought of as a broad risk factor for improving the delivery of DOT programme; and empowerment or control over one's destiny, as an important strategy. These findings need to be characterized as preliminary until the concepts can be tested directly in the Limpopo Province of South Africa. If these findings hold, health promotion practitioners should begin

\section{Appendix I}

Demographic and socio-economic predictors of non-compliance with treatment

\begin{tabular}{|c|c|}
\hline Variable & Description \\
\hline Sex & Patient's sex. Coded 0 for men, 1 for women \\
\hline Age & Patient's age, measured in years \\
\hline Marital status & Coded 0 for single or divorced or widowed, 1 if married or living with partner \\
\hline Type of family & The type of the patient's family: either nuclear coded 0 or joint coded 1 \\
\hline Size of family & Number of persons of the patient's family \\
\hline Education & $\begin{array}{l}\text { Patient's formal schooling. Coded } 0 \text { if no formal schooling (illiterate), } 1 \text { if primary, } 2 \\
\text { if secondary, and } 3 \text { tertiary }\end{array}$ \\
\hline $\begin{array}{l}\text { Occupation of } \\
\text { patient }\end{array}$ & $\begin{array}{l}\text { Coded } 0 \text { if none, } 1 \text { housewife, } 2 \text { gardener, } 3 \text { security officer, driver, } \\
\text { mechanic, } 4 \text { if police officer, } 5 \text { if teacher and } 6 \text { if lecturer, businessman, manager }\end{array}$ \\
\hline Place of residence & Place of habitat of the patient. Coded 1 if rural, 2 if urban \\
\hline Income & $\begin{array}{l}\text { Coded } 0 \text { if none, } 1 \text { if R 1-R999, } 2 \text { if R1000-R2999, } 3 \text { if R3000-R6999, } 4 \text { if R7000 } \\
\text { above }\end{array}$ \\
\hline Type of house & $\begin{array}{l}\text { The type of house the patient lived in. Coded } 1 \text { for Mukhukhu/zozo, } 2 \text { for thatched } \\
\text { mud house, } 3 \text { for thatched brick house, } 4 \text { mud house with corrugated iron, } 5 \text { brick } \\
\text { house with corrugated iron, and } 6 \text { for brick house with tiles }\end{array}$ \\
\hline Type for fuel & $\begin{array}{l}\text { The type of fuel used in a household to cook, Coded } 1 \text { for firewood, } 2 \text { for paraffin, } \\
3 \text { for gas, and } 4 \text { for electricity }\end{array}$ \\
\hline Religion & $\begin{array}{l}\text { Coded } 0 \text { if African or traditional religion, } 1 \text { if healing church (Zion Christian } \\
\text { Church, Apostolic), and } 2 \text { if Christian Protestant or Catholic }\end{array}$ \\
\hline
\end{tabular}

history of TB and $60 \%$ knew someone who had TB in the community.

\section{Limitations}

In common with other researchers' findings was that the factors associated with compliance and non-compliance seem to differ, and in some areas no clear differences were found to different studies (Khan, Walley, Newell and Naghma, 2000: 247).

\section{Conclusion}

This study has proved useful in the determination of factors adopting an empowerment education approach. Researchers need to measure more accurately the psychological, interpersonal, organizational and community changes that can occur as people participate in their communities to improve individual and social health. This should be reflected in a systematic planning process, which seeks to empower individuals with understanding, motivation and skills; and an active engagement in community affairs to improve their quality of life.

\section{Acknowledgements}

We would like to thank the patients involved in this study for their cooperation, staff of the hospitals involved for their as- 


\section{$X=$ No of messages given $\quad Y=$ No of messages recalled}

\begin{tabular}{|c|c|c|c|c|c|}
\hline Messages given & $\begin{array}{c}\text { Type of } \\
\text { message given }\end{array}$ & $\mathrm{X}$ & Messages recalled & $\begin{array}{l}\text { Type of } \\
\text { messages } \\
\text { recalled }\end{array}$ & $\bar{Y}$ \\
\hline $\begin{array}{l}\text { [\#25] } \\
\text { - You have got TB. } \\
\text { - It takes six months be cured when you take } \\
\text { treatment correctly. } \\
\text { - You have to come back after two so that we check } \\
\text { how treatment works and when you are better we give } \\
\text { further treatment which you take for four months and } \\
\text { then we check you if you are cured. } \\
\text { - We are going to look for someone in the community } \\
\text { who will supervise you while taking treatment. } \\
\text { - The TB officer will accompany home when you are } \\
\text { discharged. } \\
\text { - Every time when you take medication you must tick } \\
\text { on the green card. } \\
\text { - If you take your treatment regularly you will } \\
\text { completely get cured. }\end{array}$ & $\begin{array}{l}\text { Diagnosis (1), } \\
\text { Treatment } \\
\text { duration (1), } \\
\text { Treatment } \\
\text { course (3), } \\
\text { Support } \\
\text { available (1) } \\
\text { Prognosis (1) }\end{array}$ & 7 & $\begin{array}{l}\text { - They said TB takes } \\
\text { six months to be cured. } \\
\text { - They said I have take } \\
\text { this pills for two } \\
\text { months and then they } \\
\text { will others pills. } \\
\text { - They said the TB } \\
\text { officer will explain to } \\
\text { me treatment works. }\end{array}$ & $\begin{array}{l}\text { Treatment } \\
\text { duration } \\
\text { (1), } \\
\text { Treatment } \\
\text { course (1), } \\
\text { Support } \\
\text { available } \\
\text { (1) }\end{array}$ & 3 \\
\hline $\begin{array}{l}\text { [\#27] } \\
\text { - You have got TB. } \\
\text { - TB is curable if you take medication properly. } \\
\text { - You are going to take treatment for six months. } \\
\text { - You have to come back after two so that we check } \\
\text { how treatment works and when you are better we give } \\
\text { further treatment which you take for four months and } \\
\text { then we check you if you are cured. } \\
\text { - If you don't take treatment you will be admitted here } \\
\text { again and the disease will be worse. }\end{array}$ & $\begin{array}{l}\text { Diagnosis (1), } \\
\text { Prognosis (1), } \\
\text { Treatment } \\
\text { duration (1), } \\
\text { Treatment } \\
\text { course (1) } \\
\text { Treatment } \\
\text { adherence (1) }\end{array}$ & 5 & $\begin{array}{l}\text { - They said I should } \\
\text { not stop taking } \\
\text { treatment. } \\
\text { - They said I have to } \\
\text { take treatment for six } \\
\text { months. }\end{array}$ & $\begin{array}{l}\text { Treatment } \\
\text { duration } \\
\text { (1), } \\
\text { Treatment } \\
\text { adherence } \\
\text { (1) }\end{array}$ & 2 \\
\hline $\begin{array}{l}\text { [\#39] } \\
\text { - Sputum results show that you got TB. } \\
\text { - You have to take treatment for six months. } \\
\text { - You must be supervised while taking treatment, to } \\
\text { be sure that you're taking it. } \\
\text { - The TB officer will drive you home and explain. } \\
\text { other things you have to know about TB treatment. } \\
\text { - You have to come back after two so that we check } \\
\text { how treatment works and when you are better we give } \\
\text { further treatment which you take for four months and } \\
\text { then we check you if you are cured. } \\
\text { - Some patients do not finish their treatment, after two } \\
\text { months or so they stop thinking they are cured, don't } \\
\text { follow suit, because illness come back and you'll } \\
\text { infect those around you. }\end{array}$ & $\begin{array}{l}\text { Diagnosis (1) } \\
\text { Treatment } \\
\text { duration (1) } \\
\text { Adherence to } \\
\text { treatment (1) } \\
\text { Results of } \\
\text { non- } \\
\text { compliance } \\
\text { (1) } \\
\text { Support } \\
\text { available (1) } \\
\text { Treatment } \\
\text { course (1) }\end{array}$ & 6 & $\begin{array}{l}\text { - He said when one is } \\
\text { suffering from TB he } \\
\text { should tell the doctor } \\
\text { everything that he } \\
\text { feels. } \\
\text { - He said I should take } \\
\text { treatment for six } \\
\text { months. } \\
\text { - I have to tick on the } \\
\text { green card every time I } \\
\text { take medication. } \\
\text { - He said there would } \\
\text { be a person to } \\
\text { supervise me while } \\
\text { taking treatment. } \\
\text { - He said TB is } \\
\text { infectious. }\end{array}$ & $\begin{array}{l}\text { Treatment } \\
\text { duration } \\
\text { (1) } \\
\text { Adherence } \\
\text { to } \\
\text { treatment } \\
(1) \\
\text { Treatment } \\
\text { course (2) }\end{array}$ & 4 \\
\hline
\end{tabular}


sistance in facilitating access to patients. The World Health Organisation funded this study.

\section{References}

BARNHOORN, F \& ADRIAANSE, H 1992: In search of factors responsible for non-compliance among tuberculosis patients in Wardha district, India. Social Science \& Medicine. 34: 291-306.

BOESCH, EE 1988: Doctor patient interaction in Thailand. Saarbrücken: Institute for Social Psychological Development Planning.

BROUWER, JA; BOEREE, MJ; KAGER, P; VARKEVISSER, CM \& HARRIES, AD 1998: Traditional healers and pulmonary tuberculosis in Malawi. International Journal of Tuberculosis \& Lung Disease. 2: 231-234.

CHAULET, P 1987: Compliance with anti-tuberculosis chemotherapy in developing countries. Supplement to Tubercle $68: 19-24$.

DALAL, AK \& SINGH, AK 1992: Role of causal and recovery beliefs in psychological adjustment to a chronic case. Psychologv and Health. 6: 193-203.

COMOLET, TM; RAKOTOMALALA, R \& RAJAONARIOA, H 1998: Factors determining compliance with tuberculosis treatment in an urban environment, Tamatave, Madagascar. International Journal of Tuberculosis \& Lung Disease. 2: 891-897.

DE VILLIERS, S 1991: Tuberculosis in anthropological perspective. South African Journal of Ethnologv. 14: 69-72.

ENARSON, DA; GROSSET, J; MWINGA, A; HERSHFIELD, K; O'BRIEN, R; COLE, S \& REICHMAN, L 1995: The challenge of tuberculosis on global control and prevention. The Lancet. 346: 809-819.

FLOYD, K; WILKINSON, D \& GILKS, C 1997: Comparison of cost effectiveness of directly observed treatment (DOT) and conventionally delivered treatment for tuberculosis: experience from rural South Africa. British Medical Journal, 315: 1407-1411.

FOURIE, PB 2000: TB in South Africa: the burden of tuberculosis in South Africa. www.healthnet.org.za.

GARNER, P 1998: What makes DOT work? The Lancet 352: 1326-1327.

GLATTHAAR, E \& BERENDS, LJA 1995: The community and TB control: a success story. The Community and TB Control. 6: 179-186.

JARAMILLO, E 1999: Tuberculosis and stigma: predictors of prejudice against people with tuberculosis. Journal of Health Psychology. 4: 71-79.

KHAN, A; WALLEY, J; NEWELL, J \& NAGHMA, I 2000: Tuberculosis in Pakistan: socio-cultural constraints and opportunities in treatment. Social Science \& Medicine. 50:
247-254.

KLEINMAN, A 1980: Patients and healers in the context of culture. Boston: Harvard University Press.

LIEFOOGHE, R; BALIDDAWA, JB; KIPRUTO, H; VERMEIRE, C \& DE MUNYNCK, AO 1997: From their own perspective: a Kenyan community's perception of tuberculosis. Tropical Medicine and International Health. 2: 809821.

LIAM, CK; LIM, KH; WONG, CM \& TANG, BG 1999: Attitudes and knowledge of newly diagnosed tuberculosis patients regarding the disease, and factors affecting treatment compliance. International Journal of Tuberculosis \& Lung Disease. 3: 300-309.

MACLACHLAN, M 1997: Culture and health. Chichester: John Wiley.

MATA, JI 1985: Integrating the client's perspective in planning a tuberculosis education and treatment program in Honduras. Medical Anthropology. 9: 57-64

METCALF, CA; BRADSHAW, D \& STINDT, WW 1990: Knowledge and beliefs about tuberculosis among non-working women in Ravensmead, Cape Town. South African Medical Journal. 77: 408-411.

NAZAR-STEWART, V \& NOLAN, CM 1992: Results of a directly observed intermittent isoniazid preventive therapy program in a shelter for homeless men. American Review of Respiratory Disease. 146: 57-60.

NICHTER, M 1994: Illness semantics and international health: the weak lungs/TB complex in the Philippines. Social Science \& Medicine. 38: 649-663.

NIVEN, N 1994: Health psychology. Edinburgh: Churchhill Livingstone.

NUWAHA, F 1997: Factors influencing completion of treatment among tuberculosis patients in Mbarara District, Uganda. East African Medical Journal. 74: 690-693.

O'LEARY, A 1985: Self-efficacy and health. Behaviour Research and Therapv. 23(4): 437-451.

PELTZER, K 1998: A community survey of traditional healers in South Africa (Northern Province). South African Journal of Ethnology. 21: 191-198.

PELTZER, K 2001: Factors at follow-up associated with adherence with directly observed therapy (DOT) for tuberculosis patients in South Africa. Journal of Psvchologv in Africa. 11(2): 165-185.

RIDEOUT, M \& MENZIES, R 1994: Factors affecting compliance with preventive treatment for tuberculosis at Mistassini Lake, Quebec, Canada. Clinical \& Investigative Medicine. 17: 31-36.

RUBEL, AJ \& GARRO, LC 1992: Social and cultural fac- 
SBARBARO, JA 1990: The patient-physician relationship: compliance revisited. Annals of Allergy. 64: 325- 331.

STEEN, TW \& MAZONDE, GN 1999: Ngaka ya setswana, ngaka ya sekgoa or both? Health seeking behaviour in Botswana with pulmonary tuberculosis. Social Science \& Medicine. 48: 163-172.

SUMARTOJO, E 1993: When tuberculosis treatment fails: a social behavioral account of patient adherence. American Journal of Respiratory and Critical Care Medicine. 147: 13111320.

VECHIATO, NL 1997: Sociocultural aspects of tuberculosis control in Ethiopia. Medical Anthropology Ouarterly. 11: 183-201.

WERF, VDTS; DADE, GK \& VAN DER MAEK, F 1990: Patient compliance with tuberculosis treatment in Ghana: factors influencing adherence to therapy in a rural service programme. Tubercle. 71: 247-252.

WESTAWAY, M; CONRADIE, PW \& REMMERS, L 1991: Supervised outpatient treatment of tuberculosis: evaluation of a South African rural programme. Tubercle. 72: 140144.

WESTAWAY, M \& WOLMARANS, L 1994: Cognitive and affective reactions of black urban South Africans towards tuberculosis. Tubercle and Lung Disease. 75: 447-453.

WILKINSON, D 1994: High-compliance tuberculosis treatment programme in a rural community. Public Health. 343: 647-648.

WILKINSON, D \& DAVIES, GR 1997: Coping with Africa's increasing tuberculosis burden: are community supervisors an essential component of the DOT strategy? Tropical Medicine and International Health. 2: 700-704. 